Bulut, K. (2020). Açık öğretim ortaokulu Türkçe ders kitaplarındaki metinlerin tür ve tema açısından incelenmesi. Ana Dili Eğitimi Dergisi, 8(3), 931-949.

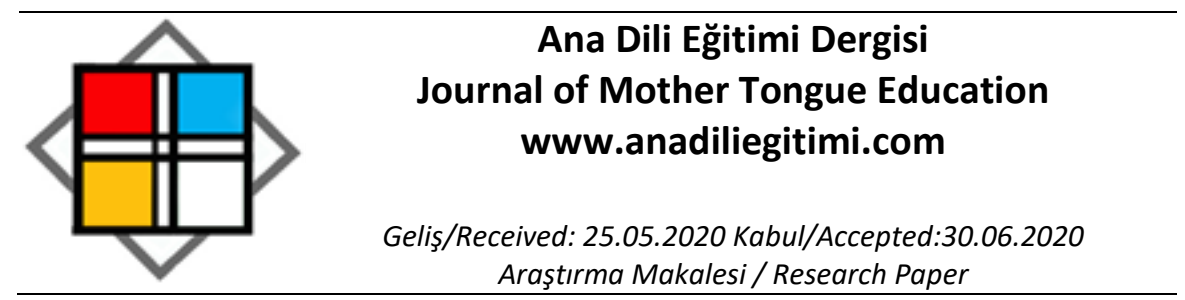

\title{
Açık Öğretim Ortaokulu Türkçe Ders Kitaplarındaki Metinlerin Tür ve Tema Açısından Incelenmesi
}

\author{
Kenan BULUT*
}

Öz

Bu çalışmanın amacı, Açık Öğretim Ortaokulu 5, 6, 7 ve 8. sınıf Türkçe ders kitaplarındaki metinleri, tür ve tema açısından incelemektir. Bu amaç çerçevesinde söz konusu kitaplarda hangi tema ve metin türlerine yer verildiği tespit edilmiş ve metin türlerinin kullanım sıklı̆̆ı belirlenmiştir. Ayrıca araştırma kapsamında, 2018 Türkçe Öğretim Programı́nda yer alan zorunlu temalara ders kitaplarında yer verilip verilmediği, seçmeli temalar ile metin türlerinin hangilerine yer verildiği, hangilerine yer verilmediği, metin türlerinin temalara ve kitabın tamamına dengeli bir şekilde dağılıp dağılmadığına da bakıımıştır. Çalışma nitel araştırma yöntemlerinden doküman incelemesine göre yürütülmüştür. Araştırmanın çalışma materyalini, 2019-2020 Eğitim ve Öğretim Yılı'nda Açık Öğretim Ortaokulu 5, 6, 7 ve 8. sınıflarında okutulan Türkçe ders kitapları oluşturmaktadır. Çalışmada elde edilen veriler betimsel analizle çözümlenmiş, sıklık açısından değerlendirilmiş ve yorumlanmıştır. Çalışmanın sonunda Açık Öğretim Ortaokulu Türkçe ders kitaplarının tür ve tema açısından zengin olduğu, kitaplarda zorunlu temaların yanı sıra birçok seçmeli temanın da yer aldığı, ancak Vatandaşık, Duygular ve Hak ve Özgürlükler temalarına hiçbir sınıf düzeyinde yer verilmediği görülmüştür. Ayrıca Program'da olan bazı türlere ders kitaplarında yer verilmediği, bazılarına ise çok az sayıda yer verildiği tespit edilmiştir.

Anahtar Kelimeler: Açık Öğretim Ortaokulu, Türkçe ders kitapları, metin, tür, tema.

\section{Analysis of Texts in Open Education Secondary School Turkish Textbooks for Themes and Text Types}

\begin{abstract}
The aim of this study was to analyze the texts in the Open Education Secondary School fifth-, sixth, seventh-, and eighth-grade Turkish textbooks in terms of type and theme. The study determined what kind of themes and texts the books consisted of and how often they made use of kinds of texts. The study investigated whether the books addressed the compulsory themes in the 2018 Turkish curriculum, if so, which of the elective themes and text types are contained and which are not, and whether the texts were distributed equally to the themes and the whole book. This was a document review, which is a qualitative research method. The study material consisted of the 2019-2020 open education secondary school fifth-, sixth-, seventh-, and eighth-grade Turkish textbooks of the Ministry of National Education. Data were analyzed using descriptive analysis in terms of frequency. The results show that the textbooks are rich in text-type and theme, address both compulsory themes and many elective themes but do not address the themes of Citizenship, Emotions, and Rights and Freedoms at all. The results also show that the textbooks do not make a mention of some text types while addressing some others very little.
\end{abstract}

Keywords: Open Education Secondary School, Turkish textbooks, text type, theme

*Dr. Öğr. Üyesi, Van Yüzüncü Yıl Üniversitesi, Eğitim Fakültesi, Türkçe Eğitimi Anabilim Dalı, Van, kenanbulut80@yyu.edu.tr, ORCID: 0000-0003-4771-0459 


\section{Giriş}

Metinler ses, hece, kelime ve cümle gibi birimlerin bir hiyerarşi içinde birleşmesinden meydana gelen ve bilgi, duygu ve düşünceleri ileten yazınsal yapılardır. Arapça "metn" kökünden gelen metin sözcüğü, TDK Güncel Türkçe Sözlükte "bir yazıyı biçim, anlatım ve noktalama özellikleriyle oluşturan kelimelerin bütünü; basılı veya el yazması parça, tekst" şeklinde tanımlanmıştır.

Dil incelemelerinin en doğru yolu metinden hareketle inceleme yapmaktır (Sağır, 2002). Burada nitelikli metinler kastedilmektedir. Kuşkusuz özenle hazırlanmış, dilin inceliklerini ve güzelliklerini yansıtan metinler aracılığıyla yapılan dil eğitimiyle nitelikli bir öğrenme gerçekleşecektir. "Çocuk, dünyaya gözünü dil ile açar, dünyayı dil ile algılar, kavrar, dünyaya dil ile katkıda bulunur. Dil düşüncenin, düşünce dilin yaratıcısı olduğuna göre çocuğun kişiliği de dille biçimlenmiş olacaktır" (Derman, 2008, s. 16). Bu nedenle dil yetkinliğinden yoksun, dünyayı çocuğa açmayan kuru metinlerin yerini seçkin metinler aldığında çocuğun düşünce, duygu eğitimi gerçekleştirilmiş olacaktır (Binyazar, 1983). Bu nedenle ana dilin "akıcılığı, yalınlığı, deyimleme ve mecaz gücüyle düşünce ve duygu zenginliğinin yansıtıldı̆̆ı metinlerle gerçekleştirilen çalışma ve incelemeler, öğrencilere yaşantı zenginliği kazandırır" (Sever, 2011, s. 8).

Güneş (2013a), dil öğretiminde metinlerin nasıl seçileceği ve işleneceği üzerinde sistemli çalışmalar yapıldığını ve dil becerilerini geliştirmek için metin öğretimi yerine metinle öğrenme yaklaşımının uygulandığını belirtmekte, geçmişten bugüne kullanılan metinlerin edebî, üretilmiş, özgün ve özel metinler olarak karşımıza çıktığını ifade etmektedir (2013a, 2013b). Buna göre geleneksel yaklaşımların ön planda olduğu yüzyıllar boyunca dil öğretimi çalışmalarında edebî metinler; davranışçı yaklaşımla birlikte üretilmiş metinler; bilişsel yaklaşımla birlikte özgün metinler; yapılandırıcı yaklaşımla birlikte özgün ve özel metinler kullanılmaya başlanmıştır. Özgün metinler daha çok iletişim amacıyla hazırlanan, herhangi bir düzeltme ya da basitleştirmeden geçmemiş metinler olarak tanımlanırken özel metinler dil öğretiminde kullanılmak üzere özellikle sanatçılar tarafından seslendirilen ve özel olarak dinleme-anlama için hazırlanmış metinlerdir (Güneş, 2013a, 2013b).

Yapılandırıcı yaklaşıma göre hazırlanan ve 2005-2006 yıllarında sırasıyla ilköğretimin ilk ve ikinci kademesinde uygulanmaya başlanan Türkçe öğretim programları, dil öğretiminde, metin öğretiminden uzaklaşarak metinle öğrenim anlayışını ön plana çıkarmıştır. Bu yaklaşımın eğitimde yer almasıyla birlikte öteden beri var olagelen ağır edebî metinler ders kitaplarından kaldırılmış, dil öğretimi taklit, tekrar ve ezberden kurtarılmış; şartlandırmalar ve kalıp cümleler ezberletmekten uzaklaşılmıs, metin öğretimi yerine metinle öğrenme hâkim olmaya başlamıştır. Aynı programda (2006), öğrencilerin günlük hayatlarında karşılaştıkları metinleri doğru, akıcı bir biçimde ve uygun yöntemleri kullanarak okuyabilmeleri ve okuduklarını değerlendirip eleştirel bir bakış açısıyla yorumlayabilmeleri, okumayı bir alışanlık hâline getirebilmelerinin amaçlandığı ifade edilmiştir.

\section{Metin Türü}

Metin türü denildiğinde öykü, roman, deneme, makale, söyleşi, masal, destan, fabl vb. edebî türler akla gelir. Söz konusu edebî türler de kendi içinde farklı şekillerde sınıflandırılmıştır. Örneğin söyleşi de masal da birer edebî türdür. Ancak söyleşi bilgi verici, bilgilendirici vb. şekillerde adlandırılırken masal, hikâye edici metin ya da olay yazısı vb. şekilde adlandırılmıştır. Alanyazın incelendiğinde araştırmacıların metinleri bazı yönleriyle benzer, bazı yönleriyle farklı şekillerde ele aldıkları görülmektedir. Güneş (2013) metinleri öyküleyici, bilgilendirici metinler ve şiir şeklinde ele alırken Akyol (2013), hikâye edici ve bilgi vermeye dayalı metinler olmak üzere iki başık altında toplamaktadır. Aytaş (2006) ise edebî türlerin ana hatlarıyla nazım ve nesir olmak üzere iki ana başlıkta toplandığını, diğer türlerin de bu ana başlıklara bağlı olarak içerik ve şekil açısından tasniflerinin yapıldığını ifade etmektedir. 2018 Türkçe Dersi Öğretim Programı (1-8. Sınıflar)'nda ise metinler bilgilendirici, hikâye edici ve şiir olarak üç ana biçim** altında toplanmıştır.

Ders kitaplarının niteliği büyük oranda metinlerin niteliğine bağlıdır. Metinlerin niteliği ise türlerden bağımsız olarak düşünülemez. Çünkü bir metin ne kadar nitelikli olursa olsun çocuğun

\footnotetext{
** Metinlerin toplandığı başlıklar Türkçe Öğretim Programı’nda "biçim” (s. 18) olarak geçtiğinden bu çalışmada da "biçim" olarak kullanılacaktır.
} 
duyuşsal ve bilişsel seviyesine uygun bir türde yazılmamışsa ona hitap etmesi mümkün değildir. Bu nedenle türler rastgele seçilemez. Sarıkaya (2018) da metin türlerinin belirlenmesinde çocukların ilgi ve isteklerinin son derece önemli olduğunu belirtmektedir.

Ders kitapları aynı zamanda çocuğun kelime hazinesini besleyen, söz varlığını zenginleştiren önemli kaynaklardan biridir. Demir (2006, s. 220)'e göre "bu kitaplar aracıllı̆ı ile öğrenciye kazandırılması hedeflenen kelimeler, eğitim seviyesine göre önceden belirlenmesi ve kademeli olarak metinlere yerleştirilmesi gerekir". Araştırmacı buna karşın kitaplarda bulunması gereken kelime/kavram sayısının alt ve üst sınırlarının ne ders kitapları yönetmeliğinde ne de öğretim programlarında belirtildiğini ifade etmektedir. Şimdiki neslin konuşurken ve yazarken kullandığı kelime sayısının, meramını doğru ve etkili anlatmak için yeterli olmadığı, günlük hayatta müşahede ettiğimiz bir meseledir. Bunun en önemli sebeplerinden birisi hiç şüphesiz yeterince okuyup yazmamaktır. Ancak ders kitaplarına alınacak metinlerin, çocukların yaş gruplarının gereksinimlerini karşılayacak, ilgilerine hitap edecek türlerden seçilmesi ve kelime hazinesinin de onların bilişsel seviyelerini geliştirecek şekilde olması durumunda söz konusu metinler hem okuma sevgisini aşılamaya hem de yetersiz kelime hazinesi probleminin aşılmasına katkı sağlayacaktır. Böylece ilk ve ortaokul yıllarında önemli bir eksiklik giderilmiş olacaktır.

\section{Tema Kavramı ve Tematik Yaklaşım}

Tematik yaklaşım ilk olarak 2005 yılında yapılandırıcı yaklaşım esas alınarak hazırlanan öğretim programlarında göz önünde bulundurulmuştur. İlköğretim Türkçe Dersi (1-5 ve 6, 7, 8. Sınıflar) Öğretim Programları (2005-2006) da ilk olarak öğretim programlarında yer alan yapılandırıcı yaklaşım, çoklu zekâ yaklaşımı, öğrenci merkezli eğitim, bireysel farklılıklara duyarlı eğitim, sarmal ve beceri yaklaşımı (MEB, 2005) ile birlikte tematik yaklaşıma göre hazırlanan programlardandır.

Tematik sözcüğü tema kavramından türetilmiştir. "Tema" sözcüğünün kökü Fransızca "tem" sözcüğüdür ve öğretici ya da edebî bir eserde işlenen ana konu, düşünce, görüş demektir (TDK, 2020). Bu, manzum eserlerde daha çok duygu, mensur eserlerde ise fikir olarak karşımıza çıkar. Çeçen ve Çiftçi (2011), tematik eğitimin öğrencilerin belirli bir tema üzerinde etraflıca çalışmasını öngören bir eğitim modeli olarak ortaya çıktığııı, belirlenen temanın derinlemesine çalışılması ve ilgili konuların ayrıntılı bir biçimde araştııımasının, bu modelin en belirgin yönü ve yararı olarak ifade edilebileceğini belirtmişlerdir.

2005 yılından önceki öğretim programlarına göre hazırlanan ders kitaplarında daha çok konudan konuya geçme söz konusu olup tam bir öğrenme ve yeterli düzeyde bir uygulama imkânı yokken, tematik yaklaşımın programlarda yer almasıyla birlikte aynı tema çerçevesinde işlenecek metinlerin bir arada bulunması ve peşi şıra işlenmesi öğrencinin yoğunlaşmasını sağladığı gibi etkinlik yaklaşımıyla da öğrenilenlerin uygulanmasına daha çok imkân vermiştir. Coşkun (2005) da tema merkezli dil eğitiminde öğretmen ve öğrencilerin belli bir konu veya metin üzerinde çalışmaktansa birkaç konuyu ve metni içeren bir tema çerçevesinde çalıştıklarına dikkat çekmiştir. Dolayısıyla metinlerin tematik yaklaşımla verilmesi öğretim faaliyetlerinin etkililiği açısından önemlidir.

\section{Açık Öğretim Ortaokulu}

Örgün öğretim faaliyetlerinden farklı olarak açık öğretim, öğretici ile öğrenicinin bir arada bulunma zorunluluğunu ortadan kaldıran öğretim faaliyetleri sisteminin adıdır. Herhangi bir şekilde örgün öğrenime devam edemeyen öğrencilerin eğitim-öğretim faaliyetlerinden uzak kalmamak için başvurduğu ve günümüzde oldukça yoğun bir şekilde talep edilen bu sistem ortaokul, ortaöğretim, yükseköğretim düzeylerinde faaliyet göstermektedir. Ortaokul ve ortaöğretim düzeyinde Milli Eğitim Bakanlığına bağlı olarak, yükseköğretim düzeyinde ise YÖK'e bağlı üniversiteler bünyesinde öğretim yapılmaktadır.

"Çeşitli nedenlerle örgün eğitime devam edemeyen ve yaygın eğitim sürecinde kendine yer bulmaya çalışan bireylerin devam ettiği bir eğitim sistemi" (Yenen Avcı, 2016) olan açık öğretim faaliyetlerinin tarihi bundan yaklaşık iki yüz yıl öncesine uzanmaktadır. 20 Mart 1728 tarihli Boston gazetesinde mektupla steno dersleri verileceği ilanı yer almıştır. Bundan 105 yıl sonra 1833 yılında bir İsveç gazetesinde mektupla yazılı anlatım dersi verileceğine ilişkin bir ilana rastlanmıştır. Ancak 
dünyadaki ilk uzaktan eğitim uygulamasının İngiltere'de, Isaac Pitman tarafından başlatıldığı ve bunun 1840 yılına rastladığı kabul edilmektedir. Pitman bir stenograftır ve İngiltere'deki Bath'da, mektupla steno öğretmeye başlamıştır. 1856 yılına gelindiğinde, uzaktan eğitim alanında örgütlü girişimlerin başladığı görülmektedir. Daha sonra dünyada çeşitli ülkeler bu sistemi uygulamaya başlamışlardır. Türkiye'de ise uzaktan eğitim fikri ilk kez 1927 yılında, eğitim sorunlarının görüşüldüğü bir toplantıda gündeme gelmiş, halkın okur-yazar hale getirilmesinde uzaktan eğitimden yararlanılması gerektiği vurgulanmıştır. Ancak halkın yüzde $90^{\prime} ı$ ın okuma yazma bilmemesi ve bunun da ancak yüz yüze eğitimle mümkün olacağı düşüncesinden dolayı uzun süre bu sisteme geçilememiştir (Kaya, 2002).

Ülkemizde ilk defa 1956 yılında Ankara Üniversitesi Hukuk Fakültesi Banka ve Ticaret Hukuku Araştırma Enstitüsü ile uzaktan eğitim uygulaması başlamıştır. Enstitü, bankalarda çalışanlara mektupla eğitim imkânı sunmuştur. Milli Eğitim Bakanlığı bünyesindeki ilk uzaktan eğitim uygulamaları ise ilk kez 7 Kasım 1960 tarihinde "Mektupla Öğretim" adı altında ve deneme öğretimi olarak başlamıştır (Kaya, 2002).

1998-1999 eğitim öğretim yılında 68 bin 886 öğrenciyle yola çıkmış ve aynı dönemde 2 bin 897 öğrenci mezun etmiş olan (MEB, 2020) Açık öğretim ortaokulu, türlü nedenlerle ortaokula devam edemeyen ve zorunlu ortaokul yaş sınırını aşarak örgün eğitim-öğretim sisteminin dışında kalan kişilere uzaktan eğitim ilke ve yöntemleriyle her durumda, her yerde eğitim-öğretim imkânı sağlamak; bu eğitim sayesinde toplumun kültür düzeyini yükseltmek; mezun olan öğrencilerin meslek edinmelerini kolaylaştırmak ve onları bir üst öğrenime hazırlamak amacı taşıyan eğitim sisteminin ilk basamağıdır (Altunkaya, 2013).

Hayat Boyu Öğrenme Genel Müdürlüğü Açık Öğretim Daire Başkanlığına bağı olarak faaliyetlerini sürdüren ve bugün aktif öğrenci sayısı 250 bini aşmış, mezun sayısı ise 432 bin 829 olan (MEB, 2020) Açık Öğretim Ortaokulunun öğretim sistemi, örgün ortaokullarda yürütülen öğretim programlarıyla aynı olup programın uygulama şekli uzaktan eğitim teknikleri ile olmaktadır.

250 bini aşkın aktif öğrenciye sahip olan Açık Öğretim Ortaokulunun, öğretim programlarında belirlenen hedeflere ulaşması, kazanımları edindirmesi, temel ve zihinsel becerileri geliştirmesi için kaynaklarının titizlikle hazırlanması gerekmektedir. Çünkü Açık Öğretim Ortaokulunda ders kitapları açık öğretime devam eden öğrenciler için en önemli bilgi kaynağıdır. Öğrencilerin kitaplarında anlamadıkları birtakım şeyleri soracakları öğretmenlerinin olmaması ve her zaman güvenilir bilgi kaynaklarına ulaşmalarının da zor olması, ders kitaplarının önemini daha da arttırmaktadır. Yenen Avcı (2019, s. 97)'ya göre de bu öğrenciler, "zamanlarını planlı ve verimli kullanmada, düşüncelerini ödev olarak yazıya dökmede, uygun okuma ve anlama becerileri geliştirmede yüz yüze öğretim gören öğrencilere oranla daha çok sorunla ve daha sık karşılaşmaktadırlar". Dolayısıyla örgün öğretimde okuyan akranlarına göre bu öğrenciler, daha çok mağdur olma durumuyla karşı karşıya kalmaktadırlar. Bu ve benzeri nedenlerden dolayı açık öğretim faaliyetleri çerçevesinde okutulan kitapların çok daha nitelikli hazırlanması, özellikle kitaplarda yer alan metinlerin çok özenle seçilmesi, nitelikli görsellerle desteklenmesi gerekir. Çünkü öğretmensiz bir eğitimde öğrencinin edindiği/edineceği bütün bilgi ve beceriler bu metinler aracılığılla olmaktadır.

Bu çalışma çerçevesinde, Açık Öğretim Ortaokulu 5, 6, 7 ve 8. sınıf Türkçe ders kitaplarında hangi tema ve metin türlerine yer verildiği tespit edilmiş ve metin türlerinin kullanım sıklığı belirlenmiştir. Ayrıca araştırma kapsamında, 2018 Türkçe Öğretim Programı'nda yer alan zorunlu temalara ders kitaplarında yer verilip verilmediği, seçmeli temalar ile metin türlerinin hangilerine yer verildiği, hangilerine yer verilmediği, metin türlerinin temalara ve kitabın tamamına dengeli bir şekilde dağılıp dağılmadığına da bakıımıştır. Dolayısıyla çalışmanın genel amacı, Açık Öğretim Ortaokulu 5, 6, 7 ve 8. sınıf Türkçe ders kitaplarındaki metinleri, tür ve tema açısından incelemektir. Bu amaç çerçevesinde aşağıdaki sorulara yanıt aranmıştır:

Açık Öğretim Ortaokulu Türkçe ders kitaplarında;

1. Yer alan metin sayıları, türleri ve bu türlerin kullanım sıklıkları nelerdir?

2. Yer alan metin türlerinin kitapların geneline ve temalara dağılımı nasıldır?

3. Hangi temalara yer verilmiştir?

4. En çok yer verilen temalar hangileridir, hiç yer verilmeyen temalar var mıdır, varsa hangileridir? 


\section{Sınırlılıklar}

Bu çalışma, 2019-2020 yılında Açık Öğretim Ortaokulunda okutulan 5, 6, 7 ve 8. sınıf Türkçe ders kitaplarındaki toplam 32 tema ve bu temalarda yer alan toplam 96 okuma metninin tür ve tema açısından incelenmesiyle sınırlıdır.

\section{Yöntem}

Bu araştırma nitel araştırma yöntemlerinden doküman incelemesi kullanılarak yapılmıştır. Creswell (2005)'e göre dokümanlar, nitel araştırmalarda önemli veri kaynaklarıdır ve hem özel hem de resmi dokümanlar bu kapsamda ele alınabilir. Bu çalışmada incelenen dokümanlar araştırmanın amacına uygun olarak Açık Öğretim Ortaokulu 5, 6, 7 ve 8. sınıf Türkçe ders kitaplarındaki okuma metinleridir.

\section{Verilerin Toplanması}

Çalışmada veriler, nitel araştırma yöntemlerinden doküman incelemesine göre toplanmıştır. Yıldırım ve Şimşek (2008), nitel araştırmayı gözlem, görüşme ve doküman analizi gibi nitel veri toplama yöntemlerinin kullanıldığı, algıların ve olayların doğal ortamda gerçekçi ve bütüncül bir biçimde ortaya konmasına yönelik nitel bir sürecin izlendiği araştırma olarak tanımlamaktadırlar. Nitel veri iyi yapılandırılmış, zengin tanımlamalara ve sürece ilişkin ayrıntılı açıklamalara dayanır (Miles ve Huberman, 2015).

Doküman incelemesi ise araştırılması hedeflenen olgular hakkında bilgi içeren yazılı materyallerin analizine dayanır (Yıldırım ve Şimşek, 2008). Belgesel gözlem ya da belgesel tarama olarak da isimlendirilmektedir (Çepni, 2012). Belgesel tarama, belli bir amaca yönelik olarak kaynakları bulma, okuma, not alma ve değerlendirme işlemlerini kapsar (Karasar, 2007). Bu analiz türünde araştırmacı öncelikle amacına yönelik kaynakları bulur, dikkatlice okur, gerekli bilgileri not alır ve notlardan yola çıkarak birtakım değerlendirme işlemleri yapar. Bu süreçte dikkat edilmesi gereken en önemli nokta, araştırmacının kaynaklardaki bilgileri, kaynakta anlatılmak istenilen gibi anlaması ve o şekilde kullanmasıdır. Bu yöntemde daha çok yapılanlardan yola çıkılarak, genel eğilimlerin, farklı fikirlerin varlıkları biraz daha netleşmiş olur (Çepni, 2012).

Araştırmanın kuramsal temellerini ortaya koymak amacıyla öncelikle bir alanyazını taraması yapılmıştır. Çalışma konusuyla ilgili yazılan makale, tez ve diğer bilimsel çalışmalar detaylıca incelenmiştir. Tezler için YÖK Tez Araştırma Merkezinden, diğer bilimsel çalışmalar için ilgili literatürden ve kaynakçada belirtilen internet sitelerinden yararlanılmıştır. Daha sonra Açık Öğretim Ortaokulu 5, 6, 7 ve 8. sınıflarında okutulmakta olan Türkçe ders kitaplarındaki metinler "tür" ve "tema" yönünden incelenmiştir. Çalışmanın amacı doğrultusunda gerekli notlar çıkarılarak yazmaya hazırlık yapılmıştır.

\section{Çalışma Materyali}

Bu araştırmanın çalışma materyalini, 2019-2020 Eğitim ve Öğretim Yılı́nda Açık Öğretim Ortaokulu 5, 6, 7 ve 8. sınıflarında okutulan Türkçe ders kitapları oluşturmaktadır. Söz konusu ders kitapları ve bu kitaplarda yer alan metin sayıları ile ilgili bilgiler aşağıdaki tabloda yer almaktadır:

\begin{tabular}{|c|c|c|c|c|c|c|}
\hline Adı & Yayın evi & $\begin{array}{c}\text { Basım } \\
\text { yılı }\end{array}$ & $\begin{array}{l}\text { Okutulduğu } \\
\text { öğretim yılı }\end{array}$ & Yazarı & $\begin{array}{l}\text { Tema } \\
\text { sayısı }\end{array}$ & $\begin{array}{l}\text { Metin } \\
\text { sayısı }\end{array}$ \\
\hline $\begin{array}{l}\text { Ortaokul ve İmam } \\
\text { Hatip Ortaokulu } \\
\text { Ders Kitabı } 5\end{array}$ & MEB Yayınları & 2018 & $\begin{array}{l}2018-2019 \\
2019-2020\end{array}$ & $\begin{array}{l}\text { Hülya Ağın Haykır } \\
\text { Hüseyin Kaplan } \\
\text { Ali Kıryar } \\
\text { Rasim Tarakcı } \\
\text { Ercan Üstün }\end{array}$ & 8 & 24 \\
\hline $\begin{array}{l}\text { Açık Öğretim Daire } \\
\text { Başkanlığı Türkçe } 6\end{array}$ & $\begin{array}{l}\text { MEB Hayat Boyu } \\
\text { Öğrenme Genel } \\
\text { Müdürlüğü }\end{array}$ & 2019 & $2019-2020$ & Abdulkadir Altan & 8 & 24 \\
\hline
\end{tabular}




\begin{tabular}{|c|c|c|c|c|c|c|}
\hline $\begin{array}{l}\text { Açık Öğretim Daire } \\
\text { Başkanlığı Türkçe } 7\end{array}$ & $\begin{array}{l}\text { MEB Hayat Boyu } \\
\text { Öğrenme Genel } \\
\text { Müdürlüğü }\end{array}$ & 2019 & $2019-2020$ & Gönül Metin & 8 & 24 \\
\hline $\begin{array}{l}\text { Açık Öğretim Daire } \\
\text { Başkanlığı Türkçe } 8\end{array}$ & $\begin{array}{l}\text { MEB Hayat Boyu } \\
\text { Öğrenme Genel } \\
\text { Müdürlüğü }\end{array}$ & 2019 & $2019-2020$ & Osman Babadağ & 8 & 24 \\
\hline \multicolumn{5}{|c|}{ Toplam } & 32 & 96 \\
\hline
\end{tabular}

Bu kitaplardan 6, 7, ve 8. sınıf öğrencileri için olanları Açık Öğretim Ortaokulu öğrencilerine yönelik olarak hazırlanmışken 5 . sınıf öğrencileri için olanı, örgün öğretime devam eden ortaokul ve imam hatip ortaokulu öğrencileriyle ortak olarak kullanılan bir kitaptır.

\section{Verilerin Analizi ve Yorumlanması}

Bu çalışmada elde edilen veriler betimsel analizle çözümlenmiştir. Betimsel analiz içerik analizine göre daha yüzeysel bir analiz yöntemidir. Bu analizde elde edilen veriler, önceden belirlenmiş başlıklar altında özetlenir ve yorumlanır. Amaç, elde edilen bulguları, düzenlenmiş ve yorumlanmış bir biçimde okuyucuya sunmaktır (Yıldırım ve Şimşek, 2008).

Veriler toplandıktan sonra çalışma için betimsel analiz yöntemine uygun bir çerçeve oluşturulmuş ve temalar belirlenmiştir. Temaları belirleme sürecinde alanyazın taranmış, benzer çalışmalara bakılmış, ayrıca uzman görüşüne başvurulmuştur. Daha sonra araştırmacı uzman görüşünü ve literatür taramasından elde edilen bilgileri de dikkate alarak çalışmanın alt amaçları doğrultusunda temaları belirlemiştir. Temalar altında oluşturulan bulgular frekanslarla sunulmuş ve yorumlanmıştır.

\section{Geçerlilik ve Güvenirlik}

Cansız Aktaş (2014)'a göre doküman incelemede, geçerlilik ve güvenirliğin sağlanması için verilerin inandırıcılığı büyük önem taşımaktadır. Verilerin açık ve tutarlı sunulması ve bir başka araştırmacının teyidinin alınması önerilmektedir.

Nitel araştırmalarda uzman incelemesi iki şekilde yapılabilir. Bunlardan birincisi araştırmacı ile bir başka uzmanın bir araya gelerek değerlendirme toplantısı yapmalarıdır. Araştırmacı bu toplantıda bütün süreci uzmana aktarır ve uzmanla birlikte değerlendirme yapar. Uzmanın çalışma ile ilgili sorularına cevap verir. Başvurulan diğer yol ise araştırmacının uzmana bütün verileri göndermesi şeklindedir. Uzman verileri inceledikten sonra görüşünü araştırmacıya bildirir. Her iki yaklaşımda da asıl amaç, araştırmacının yaklaşımının geçerliğini değerlendirmek ve başka bakış açısıyla geri bildirimde bulunmaktır (Yıldırım ve Şimşek, 2008).

Bu çalışmanın yürütülmesi sürecinde bazı metinlerin hangi türden olduğuyla ilgili ders kitaplarında herhangi bir bilgi bulunamamıştır. Bu metinlerden bazılarının türüne ilişkin uzmanlar arasında çeşitli fikir ayrılıklarının da söz konusu olduğu görülmüştür. Hangi türe ait olduğu konusunda kesin bir fikre varılamayan metinler için araştırmacı, alan uzmanı başka bir araştırmacının görüşüne başvurmuştur. Ayrıca gerekli görüldüğünde konuyla ilgili yazılan bilimsel çalışmalara da bakıımıştır. Alan uzmanının dönütü ve literatürden edinilen bilgiler ışığında ilgili metinler uygun türlere dâhil edilmiştir.

\section{Bulgular}

Bu bölümde çalışmanın verilerinden elde edilen bulgulara yer verilmiş ve bunlarla ilgili çeşitli yorumlar yapılmıştır. Çalışmanın bulguları her sınıf düzeyi için ayrı ayrı ele alınmıştır.

Açık Öğretim Ortaokulu 5. sınıf Türkçe ders kitaplarındaki metin türleri, bu türlerin kullanım sıklığı, temalar ve metin biçimlerinin temalara dağılımı ile ilgili bilgiler Tablo 1 ve 2'de yer almaktadır. 
Tablo 1.

Açık Öğretim Ortaokulu 5. Sınıf Türkçe Ders Kitabında Yer Alan Metin Türleri ve Bu Türlerin Kullanım Sıklığı

\begin{tabular}{|c|c|c|}
\hline 2018 Programı'nda yer verilen türler & Kitapta yer alan türler & $\mathrm{F}$ \\
\hline \multicolumn{3}{|c|}{ Bilgilendirici metinler } \\
\hline Anı & Anı & 1 \\
\hline Dilekçe & --- & --- \\
\hline Efemera ve Broşür & Broşür & 1 \\
\hline e-posta & --- & --- \\
\hline Haber metni, reklam & Haber metni (tanıtma yazısı) & 3 \\
\hline $\begin{array}{l}\text { Kılavuzlar (kullanım kılavuzları, tarifname, } \\
\text { talimatnameler vb.) }\end{array}$ & Tarifname (tarif yazısı) & 1 \\
\hline Makale/Fıkra/Söyleşi/Deneme & Fıkra/Söyleşi/Deneme & $1 / 1 / 1$ \\
\hline Mektup & --- & --- \\
\hline $\begin{array}{l}\text { Özlü Sözler (vecize, atasözü, deyim, } \\
\text { aforizma, duvar yazıları, motto, döviz vb.) }\end{array}$ & --- & --- \\
\hline Sosyal Medya Mesajları & --- & --- \\
\hline--- & Biyografi & 1 \\
\hline \multicolumn{3}{|c|}{ Hikâye edici metinler } \\
\hline Çizgi Roman & --- & --- \\
\hline Fabl & Fabl & 1 \\
\hline Hikâye & Hikâye & 5 \\
\hline Karikatür & Karikatür & 1 \\
\hline Masal/Efsane/Destan & --- & --- \\
\hline Mizahi Fıkra & --- & --- \\
\hline Roman & --- & --- \\
\hline Tiyatro & Tiyatro & 1 \\
\hline \multicolumn{3}{|c|}{ Şiir } \\
\hline Şarkı/Türkü & --- & --- \\
\hline Şiir & Şiir & 6 \\
\hline \multicolumn{2}{|c|}{ Toplam } & 24 \\
\hline
\end{tabular}

Tablo 1'in birinci sütununda, 2018 Türkçe Öğretim Programı'na göre ders kitaplarında yer verilecek türler yer almaktadır. Bu türlerin tamamına ders kitaplarında yer vermek elbette mümkün değildir. Zaten 2018 Programı'nı 2006 Programı'ndan ayıran önemli farklardan birisi de sınıf seviyesine göre ders kitaplarında yer alacak zorunlu türlerin olmamasıdır. Programda yer alan tablodaki metin türlerine bağlı kalınarak "hangi temada, hangi metin türlerinin yer alacağı ders kitabı yazarının/yazarlarının tercihine bağlıdı" (MEB, 2019, s. 17). Ancak ilke olarak metin türlerinin temalar arasında, kitap bütününde dengeli bir şekilde dağılımının sağlanması gerekliliği vurgulanmıştır.

Tablo incelendiğinde, Açık Öğretim Ortaokulu 5. sınıf Türkçe ders kitabında en fazla bilgilendirici metinlere (10), ardından hikâye edici metinlere (8), en az da şiir biçimindeki metinlere (6) yer verildiği görülmektedir. Tür olarak bakıldığında ise kitapta en fazla şiir (6), ardından hikâye (5), ardından haber metni (3) yer almaktadır. Bunların dışında ders kitabında yer alan anı, broşür, tarifname, fıkra, söyleşi, deneme, biyografi, fabl, karikatür ve tiyatro türünde de 1'er metne yer verilmiştir. 24 farklı metnin yer aldığı kitapta, toplam 13 farklı türün olduğu görülmektedir.

Tabloya göre Program'da olan (5. sınıf ders kitapları için) metin türlerinden anı, efemera ve broşür, haber metni, tarifname, fıkra, söyleşi, deneme, fabl, hikâye, karikatür, tiyatro ve şiirin yer aldığı; dilekçe, e-posta, makale, mektup, özlü sözler, sosyal medya mesajları, çizgi roman, masal, efsane, destan, mizahi fıkra, roman, şarkı/türkünün ise yer almadığı görülmektedir.

Program'a göre sadece 7 ve 8 . sınıf seviyesinde yer alan biyografi türünden de bir metne 5 . sınıf ders kitabında yer verilmesi dikkat çekicidir. 
Tablo 2.

Açık Öğretim Ortaokulu 5. Sınıf Türkçe Ders Kitabında Yer Alan Temalar ve Metin Biçimlerinin Temalara Dağılımı

\begin{tabular}{cccc|cccccc}
\hline $\begin{array}{c}\text { Metin } \\
\text { biçimleri }\end{array}$ & Erdemler & $\begin{array}{c}\text { Millî } \\
\text { Kültürümüz }\end{array}$ & $\begin{array}{c}\text { Mücadele } \\
\text { ve } \\
\text { Atatürk }\end{array}$ & $\begin{array}{c}\text { Çocuk } \\
\text { Dünyası }\end{array}$ & $\begin{array}{c}\text { Bilim ve } \\
\text { Teknoloji }\end{array}$ & $\begin{array}{c}\text { Okuma } \\
\text { Kültürü }\end{array}$ & $\begin{array}{c}\text { Sağlık } \\
\text { ve } \\
\text { Spor }\end{array}$ & $\begin{array}{c}\text { Doğa } \\
\text { ve } \\
\text { Evren }\end{array}$ & Toplam \\
\hline Bilgilendirici & - & 1 & 2 & - & 3 & 1 & 2 & 1 & 10 \\
\hline Hikâye edici & 3 & 1 & - & 2 & - & 1 & - & 1 & 8 \\
\hline Şiir & - & 1 & 1 & 1 & - & 1 & 1 & 1 & 6 \\
\hline Toplam & 3 & 3 & 3 & 3 & 3 & 3 & 3 & 3 & 24 \\
\hline
\end{tabular}

Tablo 2 incelendiğinde Açık Öğretim Ortaokulu 5. sınıf Türkçe ders kitabında, 2018 Türkçe Dersi Öğretim Programı́nda her sınıf düzeyinde işlenmesi zorunlu olan "Erdemler", "Millî Kültürümüz", "Millî Mücadele ve Atatürk" temalarıyla kitap yazarlarının tercihine bırakılan temalardan "Çocuk Dünyası", "Bilim ve Teknoloji", "Okuma Kültürü", "Sağlık ve Spor" ve "Doğa ve Evren” temaları olmak üzere 8 temaya yer verildiği görülmektedir.

Ders kitabında metin türlerinin dağılımına bakıldığında ise "Millî Kültürümüz", "Okuma Kültürü", "Doğa ve Evren" temalarında hem bilgilendirici hem hikâye edici metinlere hem de şiir biçimindeki metinlere yer verilirken "Erdemler", "Çocuk Dünyası" temalarında bilgilendirici metinlere; "Millî Mücadele ve Atatürk", "Bilim ve Teknoloji”, "Sağlık ve Spor" temalarında hikâye edici metinlere; "Erdemler", "Bilim ve Teknoloji" temalarında ise şiir biçimindeki metinlere yer verilmemiştir.

Kitabın geneline ve temalara bakıldığında üç biçim altındaki türlerin birbirine yakın sayılarda olduğu görülmektedir. Bu da metin türlerinin kitabın geneline ve temalara dengeli bir şekilde dağıtıldığını göstermektedir.

Açık Öğretim Ortaokulu 6. sınıf Türkçe ders kitaplarındaki metin türleri, bu türlerin kullanım sıklığı, temalar ve metin biçimlerinin temalara dağılımı ile ilgili bilgiler Tablo 3 ve 4'te yer almaktadır.

Tablo 3.

Açık Öğretim Ortaokulu 6. Sınıf Türkçe Ders Kitabında Yer Alan Metin Türleri ve Bu Türlerin Kullanım Sıklığı

\begin{tabular}{|c|c|c|}
\hline 2018 Programı'nda yer verilen türler & Kitapta yer alan türler & $f$ \\
\hline \multicolumn{2}{|c|}{ Bilgilendirici metinler } & \\
\hline Anı & --- & --- \\
\hline Blog & --- & --- \\
\hline Efemera ve Broşür & --- & --- \\
\hline e-posta & --- & --- \\
\hline Haber metni, reklam & $\begin{array}{c}\text { Haber metni/Haber metni (tanıtma } \\
\text { yazısı) }\end{array}$ & $5 / 2$ \\
\hline $\begin{array}{l}\text { Kılavuzlar (kullanım kılavuzları, tarifname, } \\
\text { talimatnameler vb.) }\end{array}$ & --- & --- \\
\hline Gezi yazısı & --- & --- \\
\hline Makale/Fıkra/Söyleşi/Deneme & Söyleşi/Deneme & $1 / 1$ \\
\hline Mektup & --- & --- \\
\hline $\begin{array}{l}\text { Özlü Sözler (vecize, atasözü, deyim, } \\
\text { aforizma, duvar yazıları, motto, döviz vb.) }\end{array}$ & --- & --- \\
\hline Sosyal Medya Mesajları & --- & --- \\
\hline--- & Dilekçe & 1 \\
\hline \multicolumn{2}{|c|}{ Hikâye edici metinler } & \\
\hline Çizgi Roman & --- & --- \\
\hline Fabl & --- & --- \\
\hline Hikâye & Hikâye & 4 \\
\hline
\end{tabular}




\begin{tabular}{|c|c|c|}
\hline Karikatür & --- & $\begin{array}{ll}-- \\
\end{array}$ \\
\hline Masal/Efsane/Destan & Masal/Efsane & $1 / 1$ \\
\hline Mizahi Fıkra & Mizahi Fıkra & 1 \\
\hline Roman & --- & --- \\
\hline Tiyatro & Tiyatro & 1 \\
\hline \multicolumn{3}{|c|}{ Şiir } \\
\hline Şarkı/Türkü & --- & --- \\
\hline Şiir & Şiir & 6 \\
\hline \multicolumn{2}{|c|}{ Toplam } & 24 \\
\hline
\end{tabular}

Tablo 3 incelendiğinde, Açık Öğretim Ortaokulu 6. sınıf Türkçe ders kitabında en fazla bilgilendirici metinlere (10), ardından hikâye edici metinlere (8), en az da şiir biçimindeki metinlere (6) yer verilmiştir. Tür olarak bakıldığında ise kitapta en fazla haber metni $(f=7)$, daha sonra şiir $(f=6)$, daha sonra hikâyeye $(f=4)$ yer verildiği görülmektedir. Söyleşi, deneme, dilekçe, masal, efsane, mizahi fıkra ve tiyatro türlerinde de $1^{\prime}$ er metne yer verilmiştir. Kitapta haber metinlerinin sayıca fazla olması $(f=7)$ kayda değer bir durumdur. 24 farklı metnin yer aldığı kitapta toplam 11 farklı türün olduğu görülmektedir.

Yukarıdaki tabloya göre 2018 Türkçe Dersi Öğretim Programı́nda olan (6. sınıf ders kitapları için) metin türlerinden haber metni, söyleşi, deneme, hikâye, masal, efsane, mizahi fıkra, tiyatro ve şiirin yer aldığı; anı, blog, efemera ve broşür, e-posta, kılavuzlar, gezi yazısı, mektup, özlü sözler, sosyal medya mesajları, çizgi roman, fabl, karikatür, roman, şarkı/türkünün ise yer almadığı görülmektedir.

Program'a göre 5, 7 ve 8 . sınıf seviyesinde yer alan ancak 6 . sınıf seviyesinde yer almayan dilekçe türünden de bir metne yer verilmesi dikkat çekicidir.

Tablo 4.

Açık Öğretim Ortaokulu 6. Sınıf Türkçe Ders Kitabında Yer Alan Temalar ve Metin Biçimlerinin Temalara Dağılımı

\begin{tabular}{|c|c|c|c|c|c|c|c|c|c|}
\hline \multirow{2}{*}{$\begin{array}{c}\text { Metin } \\
\text { biçimleri }\end{array}$} & \multicolumn{3}{|c|}{ Zorunlu temalar } & \multicolumn{6}{|c|}{ Seçmeli temalar } \\
\hline & Erdemler & $\begin{array}{c}\text { Millî } \\
\text { Kültürümüz }\end{array}$ & $\begin{array}{c}\text { Millî } \\
\text { Mücadele } \\
\text { ve Atatürk }\end{array}$ & $\begin{array}{l}\text { Kişisel } \\
\text { Gelişim }\end{array}$ & $\begin{array}{l}\text { Bilim ve } \\
\text { Teknoloji }\end{array}$ & $\begin{array}{c}\text { Zaman } \\
\text { ve } \\
\text { Mekân }\end{array}$ & $\begin{array}{l}\text { Birey ve } \\
\text { Toplum }\end{array}$ & $\begin{array}{l}\text { Doğa } \\
\text { ve } \\
\text { Evren } \\
\end{array}$ & Toplam \\
\hline Bilgilendirici & 1 & 1 & 1 & 2 & 2 & 1 & - & 2 & 10 \\
\hline Hikâye edici & 1 & 2 & 1 & 1 & - & 1 & 2 & - & 8 \\
\hline Şiir & 1 & - & 1 & - & 1 & 1 & 1 & 1 & 6 \\
\hline Toplam & 3 & 3 & 3 & 3 & 3 & 3 & 3 & 3 & 24 \\
\hline
\end{tabular}

Tablo 4 incelendiğinde, Açık Öğretim Ortaokulu 6. sınıf Türkçe ders kitabında, 2018 Türkçe Dersi Öğretimi Programı́nda her sınıf düzeyinde işlenmesi zorunlu olan "Erdemler", "Millî Kültürümüz", "Millî Mücadele ve Atatürk" temalarına yer verildiği görülmektedir. Kitap yazarlarının seçmeli temalar içinden tercih ettiği temalar ise "Kişisel Gelişim", "Bilim ve Teknoloji", "Zaman ve Mekân", "Birey ve Toplum" ve "Doğa ve Evren" temalarıdır.

Ders kitabında metin türlerinin dağılımına bakıldığında ise "Erdemler", "Millî Mücadele ve Atatürk", "Zaman ve Mekân" temalarında üç biçim altındaki türlere yer verildiği; "Birey ve Toplum" temasında bilgilendirici metinlere; "Bilim ve Teknoloji" ve "Doğa ve Evren" temalarında hikâye edici metinlere; "Millî Kültürümüz" ve "Kişisel Gelişim" temalarında ise şiir biçimindeki metinlere yer verilmediği görülmektedir. Kitabın geneline ve temalara bakıldığında üç biçim altındaki türlerin birbirine yakın sayılarda olduğu ifade edilebilir. Bu da metin türlerinin kitabın geneline ve temalara dengeli bir şekilde dağıtıldığını göstermektedir.

Açık Öğretim Ortaokulu 7. sınıf Türkçe ders kitaplarındaki metin türleri, bu türlerin kullanım sıklığı, temalar ve metin biçimlerinin temalara dağılımı ile ilgili bilgiler Tablo 5 ve 6 'da yer almaktadır. 
Tablo 5.

Açık Öğretim Ortaokulu 7. Sınıf Türkçe Ders Kitabında Yer Alan Metin Türleri ve Bu Türlerin Kullanım Sıklığı

\begin{tabular}{|c|c|c|}
\hline 2018 Programı'nda yer verilen türler & Kitapta yer alan türler & $f$ \\
\hline \multicolumn{2}{|c|}{ Bilgilendirici metinler } & \\
\hline Anı & Anı & 1 \\
\hline Biyografiler, Otobiyografiler & Otobiyografi & 1 \\
\hline Blog & --- & --- \\
\hline Dilekçe & --- & --- \\
\hline Efemera ve Broşür & --- & --- \\
\hline e-posta & --- & --- \\
\hline Günlük & --- & --- \\
\hline Haber metni, reklam & $\begin{array}{c}\text { Haber metni/Haber metni (tanıtma } \\
\text { yazısı) }\end{array}$ & $2 / 2$ \\
\hline $\begin{array}{l}\text { Kılavuzlar (kullanım kılavuzları, tarifname, } \\
\text { talimatnameler vb.) }\end{array}$ & --- & --- \\
\hline Gezi yazısı & --- & --- \\
\hline Makale/Fıkra/Söyleşi/Deneme & Söyleşi/Deneme & $1 / 3$ \\
\hline Mektup & Mektup & 1 \\
\hline $\begin{array}{l}\text { Özlü Sözler (vecize, atasözü, deyim, } \\
\text { aforizma, duvar yazıları, motto, döviz vb.) }\end{array}$ & --- & --- \\
\hline Sosyal Medya Mesajları & --- & --- \\
\hline \multicolumn{2}{|c|}{ Hikâye edici metinler } & \\
\hline Çizgi Roman & --- & --- \\
\hline Fabl & --- & --- \\
\hline Hikâye & Hikâye & 4 \\
\hline Karikatür & --- & --- \\
\hline Masal/Efsane/Destan & Efsane & 1 \\
\hline Mizahi Fıkra & --- & \\
\hline Roman & --- & --- \\
\hline Tiyatro & Tiyatro & 1 \\
\hline \multicolumn{2}{|c|}{ Şiir } & \\
\hline Şarkı/Türkü & --- & --- \\
\hline Şiir & Şiir & 7 \\
\hline \multicolumn{2}{|c|}{ Toplam } & 24 \\
\hline
\end{tabular}

Tablo 5 incelendiğinde, Açık Öğretim Ortaokulu 7. sınıf Türkçe ders kitabında en fazla bilgilendirici metinlere (11), ardından şiir biçimindeki metinlere (7), en az da hikâye edici metinlere (6) yer verilmiştir. Tür olarak bakıldığında ise kitapta en fazla şiir $(f=7)$, ardından hikâye ve haber metni $(f=4)$, ardından da deneme $(f=3)$ yer almaktadır. Anı, otobiyografi, söyleşi, mektup, efsane ve tiyatro türlerinden 1'er metnin yer aldığı kitapta, 11 farklı türden 24 metin yer almaktadır.

Tabloya göre Program'da olan (7. sınıf ders kitapları için) metin türlerinden anı, biyografi/otobiyografi, haber metni, söyleşi, deneme, mektup, hikâye, efsane, tiyatro ve şiirin yer aldığı; blog, dilekçe, efemera ve broşür, e-posta, günlük, kılavuzlar, gezi yazısı, özlü sözler, sosyal medya mesajları, çizgi roman, fabl, karikatür, mizahi fıkra, roman, şarkı/türkünün ise yer almadığı görülmektedir. 
Tablo 6.

Açık Öğretim Ortaokulu 7. Sınıf Türkçe Ders Kitabında Yer Alan Temalar ve Metin Biçimlerinin Temalara Dağılımı

\begin{tabular}{cccc|cccccc}
\hline $\begin{array}{c}\text { Metin } \\
\text { biçimleri }\end{array}$ & \multicolumn{3}{c|}{ Zorunlu temalar } & \multicolumn{5}{c}{ Seçmeli temalar } \\
\hline & Erdemler & $\begin{array}{c}\text { Millî } \\
\text { Kültürümüz }\end{array}$ & $\begin{array}{c}\text { Mücadele } \\
\text { ve } \\
\text { Atatürk }\end{array}$ & $\begin{array}{c}\text { Kişisel } \\
\text { Gelişim }\end{array}$ & $\begin{array}{c}\text { Okuma } \\
\text { Kültürü }\end{array}$ & $\begin{array}{c}\text { Zaman } \\
\text { ve } \\
\text { Mekân }\end{array}$ & Sanat & $\begin{array}{c}\text { Doğa } \\
\text { ve } \\
\text { Evren }\end{array}$ & Toplam \\
\hline Bilgilendirici & 2 & - & 1 & 1 & 3 & - & 3 & 1 & 11 \\
\hline Hikâye edici & - & 2 & 1 & 2 & - & 1 & - & - & 6 \\
\hline Şiir & 1 & 1 & 1 & - & - & 2 & - & 2 & 7 \\
\hline Toplam & 3 & 3 & 3 & 3 & 3 & 3 & 3 & 3 & 24 \\
\hline
\end{tabular}

Tablo 6 incelendiğinde, Açık Öğretim Ortaokulu 7. sınıf Türkçe ders kitabında, 2018 Türkçe Dersi Öğretimi Programı'nda her sınıf düzeyinde işlenmesi zorunlu olan "Erdemler", "Millî Kültürümüz", "Millî Mücadele ve Atatürk" temalarıyla kitap yazarlarının tercihine bırakılan temalardan "Kişisel Gelişim", "Okuma Kültürü", "Zaman ve Mekân", "Sanat" ve "Doğa ve Evren" temaları olmak üzere 8 temaya yer verildiği görülmektedir.

Metin türlerinin dağılımına bakıldığında sadece "Millî Mücadele ve Atatürk" temasında üç biçim altındaki metinlere yer verildiği, diğer temalarda böyle bir dağılımın olmadığı görülmektedir. "Erdemler", "Okuma Kültürü", "Sanat" ve "Doğa ve Evren" temalarında hikâye edici metinlere; "Kişisel Gelişim", "Okuma Kültürü" ve "Sanat" temalarında ise şiir biçimindeki metinlere yer verilmemiştir. Buna göre "Okuma Kültürü" ve "Sanat" temalarında sadece bilgilendirici metinler yer almıştır. Kitabın geneline bakıldı̆̆ında üç biçim altındaki metin türlerinin diğer ders kitaplarındakilerin aksine kitabın geneline ve temalara dengeli dağıtılmadığı ifade edilebilir. 7. sınıf öğrencilerinin bilgilendirici metinlerle daha fazla karşılaştıkları görülmektedir.

Açık Öğretim Ortaokulu 8. sınıf Türkçe ders kitaplarındaki metin türleri, bu türlerin kullanım sıkığı, temalar ve metin biçimlerinin temalara dağılımı ile ilgili bilgiler Tablo 7 ve 8'de yer almaktadır.

Tablo 7.

Açık Öğretim Ortaokulu 8. Sınıf Türkçe Ders Kitabında Yer Alan Metin Türleri ve Bu Türlerin Kullanım Sıklığı

\begin{tabular}{|c|c|c|}
\hline 2018 Programı'nda yer verilen türler & Kitapta yer alan türler & $f$ \\
\hline \multicolumn{2}{|c|}{ Bilgilendirici metinler } & \\
\hline Anı & --- & --- \\
\hline Biyografiler, Otobiyografiler & --- & --- \\
\hline Blog & --- & --- \\
\hline Dilekçe & --- & --- \\
\hline Efemera ve Broşür & --- & --- \\
\hline e-posta & --- & --- \\
\hline Günlük & --- & --- \\
\hline Haber metni, reklam & Haber metni & 2 \\
\hline $\begin{array}{l}\text { Kılavuzlar (kullanım kılavuzları, tarifname, } \\
\text { talimatnameler vb.) }\end{array}$ & -- & --- \\
\hline Gezi yazısı & Gezi yazısı & 1 \\
\hline Makale/Fıkra/Söyleşi/Deneme & Makale/Söyleşi/Deneme & $2 / 1 / 3$ \\
\hline Mektup & --- & --- \\
\hline $\begin{array}{l}\text { Özlü Sözler (vecize, atasözü, deyim, } \\
\text { aforizma, duvar yazıları, motto, döviz vb.) }\end{array}$ & --- & --- \\
\hline Sosyal Medya Mesajları & --- & --- \\
\hline \multicolumn{2}{|c|}{ Hikâye edici metinler } & \\
\hline Çizgi Roman & --- & --- \\
\hline
\end{tabular}




\begin{tabular}{l|c|c}
\hline Fabl & --- & --- \\
\hline Hikâye & Hikâye & 4 \\
\hline Karikatür & --- & -- \\
\hline Masal/Efsane/Destan & Masal/Destan & $1 / 2$ \\
\hline Mizahi Fıkra & Mizahi Fıkra & 1 \\
\hline Roman & --- & -- \\
\hline Tiyatro & Tiyatro & 1 \\
\hline \multicolumn{2}{|c|}{ Şiir } & -1 \\
\hline Şarkı/Türkü & --- & 6 \\
\hline Şiir & Şiir & 24 \\
\hline \multicolumn{2}{r|}{ Toplam } \\
\hline
\end{tabular}

Tablo 7 incelendiğinde, Açık Öğretim Ortaokulu 8. sınıf Türkçe ders kitabında, bilgilendirici ve hikâye edici metinlere 9 defa, şiir biçimindeki metinlere ise 6 defa yer verildiği görülmektedir. Tür olarak bakıldığında ise ders kitabında en fazla şiir $(f=6)$, daha sonra hikâye $(f=4)$ daha sonra deneme $(f=3)$ yer almaktadır. Kitapta haber metni, makale ve destan türlerinden 2'şer; gezi yazısı, söyleşi, masal, mizahi fıkra ve tiyatro türlerinden 1'er metne yer verilmiştir. 24 farklı metnin yer aldığı kitapta, toplam 11 farklı türün olduğu tespit edilmiştir.

Yukarıdaki tablo incelendiğinde 2018 Türkçe Dersi Öğretim Programı́nda olan (8. sınıf ders kitapları için) metin türlerinden haber metni, gezi yazısı, makale, söyleşi, deneme, hikâye, masal, destan, mizahi fıkra, tiyatro ve şiirin yer aldığı; anı, biyografi/otobiyografi, blog, dilekçe, efemera ve broşür, e-posta, günlük, kılavuzlar, mektup, özlü sözler, sosyal medya mesajları çizgi roman, fabl, karikatür, roman, şarkı/türkünün ise yer almadığı görülmektedir.

Tablo 8.

Açık Öğretim Ortaokulu 8. Sınıf Türkçe Ders Kitabında Yer Alan Temalar ve Metin Biçimlerinin Temalara Dağılımı

\begin{tabular}{|c|c|c|c|c|c|c|c|c|c|}
\hline \multirow[t]{2}{*}{$\begin{array}{c}\text { Metin } \\
\text { biçimleri }\end{array}$} & \multicolumn{3}{|c|}{ Zorunlu temalar } & \multicolumn{6}{|c|}{ Seçmeli temalar } \\
\hline & Erdemler & $\begin{array}{c}\text { Millî } \\
\text { Kültürümüz }\end{array}$ & $\begin{array}{c}\text { Millî } \\
\text { Mücadele } \\
\text { ve } \\
\text { Atatürk }\end{array}$ & $\begin{array}{l}\text { Doğa } \\
\text { ve } \\
\text { Evren }\end{array}$ & $\begin{array}{l}\text { Okuma } \\
\text { Kültürü }\end{array}$ & $\begin{array}{c}\text { Zaman } \\
\text { ve } \\
\text { Mekân }\end{array}$ & Sanat & Illetişim & Toplam \\
\hline Bilgilendirici & 1 & 1 & 2 & 2 & 1 & - & - & 2 & 9 \\
\hline Hikâye edici & 2 & 1 & - & - & 2 & 2 & 2 & - & 9 \\
\hline Şiir & - & 1 & 1 & 1 & - & 1 & 1 & 1 & 6 \\
\hline Toplam & 3 & 3 & 3 & 3 & 3 & 3 & 3 & 3 & 24 \\
\hline
\end{tabular}

Tablo 8 incelendiğinde Açık Öğretim Ortaokulu 8. sınıf Türkçe ders kitabında, 2018 Türkçe Dersi Öğretimi Programı'nda her sınıf düzeyinde işlenmesi zorunlu olan "Erdemler", "Millî Kültürümüz", "Millî Mücadele ve Atatürk" temalarına yer verildiği görülmektedir. Kitap yazarlarının seçmeli temalar içinden tercih ettiği temalar ise "iletişim", "Okuma Kültürü", "Zaman ve Mekân", "Sanat" ve "Doğa ve Evren" temalarıdır.

Metin türlerinin dağılımına bakıldığında sadece "Millî Kültürümüz" temasında üç biçim altındaki metinlere yer verildiği, diğer temalarda böyle bir dağılımın olmadığı görülmektedir. "Millî Mücadele ve Atatürk", "Doğa ve Evren" ve "iletişim" temalarında hikâye edici metinlere; "Erdemler" ve "Okuma Kültürü" temalarında ise şiirlere yer verilmemiştir.

Kitabın geneline ve temalara bakıldığında üç biçim altındaki türlerin birbirine yakın sayılarda yer aldığı ifade edilebilir. 


\section{Sonuç ve Tartışma}

Türkçe derslerinin nitelikli işlenmesinde en önemli araç kuşkusuz ders kitapları ve bu kitaplardaki metinler ve etkinliklerdir. Polat (1991) öğretim sürecinin diğer öğelerini (öğretmen ve öğrenci) teşvik eden ya da şevklerini kıran en önemli etkenlerden birinin de kullanılan ders kitapları olduğunu ifade etmektedir. Elbette ders kitaplarının niteliğini de içindeki metinlerden ve diğer unsurlardan bağımsız düşünmek mümkün değildir. Bu nedenle ders kitaplarının Türkçenin kullanım olanaklarından doğru ve yeterli düzeyde yararlanarak dilin her türlü özelliğini öğrenciye kazandırır nitelikte olması gerekmektedir (Mert, 2013).

Bu çalışmada Açık Öğretim Ortaokulu 5, 6, 7 ve 8. sınıf Türkçe ders kitaplarında hangi tema ve metin türlerine yer verildiği tespit edilmiş ve metin türlerinin kullanım sıklığı belirlenmiştir. Araştırma kapsamında 2018-2019 Eğitim ve Öğretim Yılı'ndan itibaren okutulan ve MEB Yayınevi tarafından hazırlanan Ortaokul ve İmam Hatip Ortaokulu Türkçe Ders Kitabı ile 2019-2020 Eğitim ve Öğretim Yılı'nda okutulan ve MEB Hayat Boyu Öğrenme Genel Müdürlüğü Yayınları tarafından hazırlanan Açık Öğretim Ortaokulu 6, 7 ve 8 . sınıf Türkçe ders kitapları metin türleri ve temalar bağlamında incelenmiştir.

2001 yııında yayımlanan Millî Eğitim Bakanlığı Açık Öğretim Ortaokulu Yönetmeliği, eğitim ve öğretimle ilgili beşinci bölüm 30. maddesinde, "okulda, ortaokul öğretim programlarının uygulanması esastır" (2014 yılında yapılan değişiklik) ifadesine yer vermektedir (MEB, 2001). Buna göre bütün derslerde örgün eğitimde kullanılan öğretim programlarının esas alınması gerektiğinden ders kitaplarının da öğretim programlarında belirtildiği şekilde hazırlanması gerekir. Bu yönüyle Açık Öğretim Ortaokulu Türkçe ders kitaplarının, 2017 yılında taslak şeklinde yapılan ancak 2018 yılında son şekli verilerek uygulanmaya başlanan Türkçe Dersi Öğretim Programı'na uygun olarak hazırlanması gerekmektedir.

2018 Türkçe Dersi Öğretim Programı incelendiğinde tüm sınıf düzeylerinde, ders kitaplarında 8 tema ve her temada 3 okuma, 1 dinleme/izleme, 1 serbest okuma metninin yer alacağı öngörülmüştür. Böylece bir kitapta toplamda 24 okuma, 8 dinleme/izleme ve 8 serbest okuma metni olmak üzere toplam 40 metin kullanılmış olmalıdır. Açık Öğretim Ortaokulu 5. sınıf Türkçe ders kitabı incelendiğinde kitapta 8 tema ve her temada 3 okuma, 1 dinleme/izleme ve 1 de serbest okuma metni yer almaktadır. Ancak 6, 7 ve 8. sınıf Türkçe ders kitaplarında da 8 tema ve her temada 3 okuma metni bulunmakta iken bu kitaplarda dinleme/izleme ve serbest okuma metinlerinin olmadığı görülmektedir. Bu bağlamda kitaplarda farklılıklar olduğu tespit edilmiştir. Türkçe dersinin bir dil dersi olması ve dil becerilerinin bir bütünlük içinde ele alınması gerektiği düşünüldüğünde 6,7 ve 8 . sınıf ders kitaplarında dinleme metinlerine yer verilmemiş olmasının önemli bir eksiklik olduğu söylenebilir. Örgün eğitim gören ortaokul öğrencilerine yönelik olarak yapıldığı gibi dinleme metinlerinin EBA uygulaması üzerinden sesli kayıt olarak verilip ders kitaplarında da etkinliklerinin yer alması bu eksikliği giderecektir. 2018 Türkçe Öğretim Programı'nda ders kitabında temaları destekler nitelikte edebî ve estetik değer taşıyan serbest okuma metinlerine yer verilmesi gerektiği ifade edilmiştir. Buna göre ders kitaplarında yer alacak serbest okuma metinlerinin, öğrencilere edebî ve estetik değer kazandırma konusunda katkı sağlayacağı öngörülmüştür. Bu metinlere ilişkin herhangi bir etkinliğin olmadığı da göz önüne alındığında, Açık Öğretim Ortaokulu öğrencilerinin de bu metinlerden rahatlıkla yararlanabileceği düşünülmektedir. Bu açıdan bakıldı̆̆ında bu metinlerin Açık Öğretim Ortaokulu 6, 7 ve 8 sınıf ders kitaplarında yer almaması bir eksiklik olarak değerlendirilmektedir.

2018 Türkçe Öğretim Programı incelendiğinde metin türlerinin bilgilendirici, hikâye edici ve şiir olmak üzere üç biçim altında toplandığı görülmektedir. Çalışma kapsamındaki ders kitaplarına bakıldığında 5 ve 6 . sınıf Türkçe ders kitaplarında bilgilendirici metinlere 10'ar, hikâye edici metinlere 8'er, şiir biçimindeki metinlere 6'şar defa; 7. sınıf Türkçe ders kitabında bilgilendirici metinlere 11, hikâye edici metinlere 6, şiir biçimindeki metinlere 7 defa; 8. sınıf Türkçe ders kitabında bilgilendirici ve hikâye edici metinlere 9 'ar, şiir biçimindeki metinlere 6 defa yer verildiği görülmüştür. Dört kitaptaki metinlerin toplamına bakıldığında ise bilgilendirici metinlere 40, hikâye edici metinlere 31, şiir biçimindeki metinlere 25 defa yer verildiği tespit edilmiştir. Kıbrıs (2019) da örgün eğitim Türkçe ders kitaplarında sırasıyla en fazla bilgilendirici, hikâye edici ve şiir biçimindeki metinlere yer verildiğini tespit etmiştir. 
Türlerin hem temalara dağılımı hem de tema içindeki dağııımı çok önemli bir husustur. 2018 Türkçe Öğretim Programı́nda buna özellikle dikkat çekilmiştir. Buna göre 5, 6 ve 8 . sınıf ders kitaplarında yer alan türlerin kitabın geneline ve temalara dengeli dağıtıldığı, ancak 7 . sınıf ders kitabı için aynı şeyin söylenemeyeceği tespit edilmiştir. Yukarıda görüldüğü üzere 7. sınıf ders kitabında yer alan metinlerin yaklaşık yarısını bilgilendirici metinlerin oluşturduğu (11), hikâye edici (6) ve şiir biçimindeki metinlere ise (7) aynı oranda yer verilmediği görülmüştür. Ayrıca bu sınıfa ait ders kitabında "Okuma Kültürü" temasında sadece bilgilendirici metinlere yer verilmiş, hikâye edici ve şiir biçimindeki metinlere bu temada hiç yer verilmemiştir. Oysaki okuma eylemi örgün eğitim gören öğrenciler için önemli olduğu kadar Açık Öğretim Ortaokulunda öğrenimlerini sürdüren öğrenciler için de önemlidir. Bu nedenle söz konusu temada, sadece bilgilendirici metinlerin yanı sıra okuma sevgisini kazandıracak hikâye edici ve şiir biçimindeki metinlere de yer verilmesinin daha doğru olacağı düşünülmektedir. Bu açıdan bakıldığında bu kitabın hazırlanmasında daha fazla hassasiyetin gösterilmesi gerektiği sonucuna varmak mümkündür. Ayrıca ders kitaplarının dördünde de bilgilendirici metinlerin sayısı diğerlerinden fazladır. Özellikle yaş itibariyle 5 ve 6 . sınıf öğrencilerinin somut işlemler döneminden soyut işlemler dönemine henüz geçme aşamasında oldukları göz önüne alındığında bu öğrenciler için hazırlanan kitaplarda, hikâye edici ve şiir biçimindeki metinlerin, bilgilendirici metinlerden sayıca fazla olmasının daha doğru olacağı değerlendirilmektedir.

Çalışmada 5. sınıf ders kitabında 13; 6, 7 ve 8. sınıf ders kitaplarında 11 farklı türde metne yer verildiği görülmüştür. Açık Öğretim Ortaokulu 5. sınıf Türkçe ders kitabı metinlerinde en fazla şiir $(f=6)$, hikâye $(f=5)$ ve haber metni $(f=3)$ türlerine; 6 . sınıf Türkçe ders kitabı metinlerinde en fazla haber metni $(f=7)$, şiir $(f=6)$ ve hikâye $(f=4)$ türlerine; 7 . sınıf Türkçe ders kitabı metinlerinde en fazla şiir $(f=7)$, hikâye $(f=4)$, haber metni $(f=4)$ ve deneme $(f=3)$ türlerine, 8. sınıf Türkçe ders kitabı metinlerinde en fazla şiir $(f=6)$, hikâye $(f=4)$, deneme $(f=3)$, haber metni $(f=2)$, destan $(f=2)$ ve makale $(f=2)$ türlerine yer verildiği tespit edilmiştir. Dört sınıfın toplamına bakıldığında ise en çok şiire $(f=25)$ yer verildiği, daha sonra sırasıyla hikâye $(f=17)$, haber metni $(f=16)$, deneme $(f=8)$, tiyatro $(f=4)$, söyleşi $(f=4)$ türlerine yer verildiği görülmüştür. Bunların haricinde ders kitaplarında destan $(f=2)$, makale $(f=2)$, anı $(f=2)$, masal $(f=2)$, efsane $(f=2)$, biyografi/otobiyografi $(f=2)$, mizahi fıkra $(f=2)$, fikra $(f=1)$, dilekçe $(f=1)$, mektup $(f=1)$, gezi yazısı $(f=1)$, fabl $(f=1)$, karikatür $(f=1)$, broşür $(f=1)$, tarifname $(f=1)$ türlerine de yer verilmiştir. Bu bulgu Açık Öğretim Ortaokulu Türkçe ders kitaplarının tür yönünden zengin olduğunu göstermektedir. Özbay ve Çeçen (2012) de yaptıkları çalışmada inceledikleri ders kitaplarında tür çeşitliliğinin fazla olduğunu tespit ettiklerini ve bu durumun yararlı olduğunu ifade etmişlerdir. Keklik (2009) ve Kolaç (2009) ise yaptıkları çalışmalarda ders kitaplarında tür dağılımlarının fazla olmasının önemli olduğunu ancak bu durumun ders kitapları arasında tutarsızlıklar oluşturabileceğini ve bunun da öğrencilerin bazı metin türleriyle karşılaşmayacakları anlamına geldiğini belirtmektedirler.

Açık Öğretim Ortaokulu ders kitaplarında şiir ve hikâye türlerine her sınıf düzeyinde yer verilmiş olması, hem hedef kitlenin ilgi ve ihtiyaçları hem de çocukta dil edinimi ve gelişimi açısından normal bir durumdur. Ancak özellikle tiyatro türüne ait metinlerin her sınıf düzeyinde yer bulmuş olması kayda değerdir. Yalçın ve Aytaş (2011) da tiyatronun, bireyin kişilik ve kimlik kazanmasında önemli sanat dallarından biri olduğunu ifade etmektedirler. Ancak tiyatro türündeki metinler aracılığıyla verilmek istenen mesajların yüz yüze eğitimle daha etkili olduğu/olacağı düşünülmektedir. Nitekim Yenen Avcı (2019) da çalışmasında bazı metin türlerinin açık öğretim veya uzaktan eğitime uygun olmadığını ifade etmektedir.

Incelenen ders kitaplarında, 2018 Türkçe Öğretim Programı'nda yer alan bazı türlere hiç yer verilmediği, bazılarına da çok az yer verildiği belirlenmiştir. Program'a göre anı, e-posta, makale, fıkra, mektup, özlü sözler, sosyal medya mesajları, çizgi roman, roman, fabl, karikatür, masal, şarkı/türkü türleri dört sınıf düzeyinde; blog, gezi yazısı, dilekçe üç sınıf düzeyinde; günlük, biyografi/otobiyografiler iki sınıf düzeyinde yer alan önemli türler iken bu türlerden anı, makale, masala sadece iki defa; mektup, karikatür, fıkra, fabl ve biyografi/otobiyografilere sadece bir defa yer verilmiş, diğerlerine hiçbir sınıf düzeyinde yer verilmemiştir. Alanyazında şiir başlığı (biçimi) altında yer alan şarkı/türkü türündeki metinlere örgün eğitim veren okullarda da sadece bir kere yer verildiği belirtilmiştir (Kıbrıs, 2019). Bu durum, bu yöndeki problemin sadece Açık Öğretim Ortaokulunda okutulan kitaplarla sınırlı olmadığını göstermektedir. Ceran ve Bozarslan (2013) bunun, öğrencilerin şiir 
türünü tanımamasına ve şiir zevkinden yoksun olmasına sebep olacağını belirtmektedirler. Ders kitaplarında en az yer verilen metin türlerinden biri de biyografi ve otobiyografilerdir. Öğrencilerin rol model için örnek kişiliklere en çok intiyaç duyduğu bir dönemde, toplumuna ve insanlığa yaralı birer kişi olarak yaşamlarını sürdürmüş olanların hayatlarından kesitler sunmanın ve buna ders kitaplarına konulacak metinler arasında yer vermenin önemi yadsınamaz. Yine bu ders kitaplarının hitap ettiği öğrenci kesimi düşünüldüğünde masal türüne de az yer verildiği görülmektedir. Oysaki gizemli havası ve serüven dolu fantastik olaylar içermesinden dolayı çocukların ilgisini çeken masalın (Türkben, 2018), başta dil olmak üzere çocuk gelişiminde ne kadar önemli olduğu bilinen bir gerçektir. Nitekim Pertev Naili Boratav'ın şu cümlesi masalın ders kitaplarındaki yerini göstermesi açısından önemlidir:

Çocuğa ana dilinin, bir işçi elindeki alet gibi nasıl kullanıldığını ilk öğreten, ona bu dilin türlü hünerlerini; kıvraklığını, zenginliğini, inceliğini ilk gösteren, kişiye kendi dilini konuşmayanlardan uzaklaştırıcı duyguyu -ninnilerin, tekerlemelerin, türkülerin yanı başında ama herhalde onlardan daha geniş ölçüde- ilk aşılayan masallardır (Boratav, 2018, s. 17).

2018 Türkçe Öğretim Programı'na göre 5 ve 6. sınıf ders kitabı için öngörülmemiş türlere de bu kitaplarda yer verilmiştir. 5 . sınıf ders kitabında yer verilen biyografi, 6 . sınıf ders kitabında yer verilen dilekçe türleri bu kapsamdadır. Literatürdeki bazı çalışmalarda programlarda yer verilmeyen türlerin ders kitaplarına alınmasının, türler açısından bir zenginlik olduğu belirtilmiştir (Özbay ve Çeçen, 2012). Böyle bir yarar söz konusu olmakla birlikte türlerin programların uygun gördüğü sınıf kitaplarında yer almasının daha uygun olacağı, aksi durumda ders kitabı yazarlarının sınıf seviyesine göre tür seçiminde kendi inisiyatiflerini kullanmalarının önünün açılacağı ve bunun da programlarla belirlenen standartları ortadan kaldırarak bir kargaşayı beraberinde getireceği söylenebilir.

Çalışmanın sonuçlarından birisi de haber metni ve tanıtım yazılarına fazlaca yer verilmesidir. Ders kitaplarının güncel olanı takip etmesi bağlamında bu durum son derece önemlidir. Ancak Program'a göre yer verilmesi gerektiği halde dört ders kitabında da bazı yeni ve güncel türlerin (efemera, çizgi roman, sosyal medya mesajları vb.) yer almadığı görülmektedir. Özellikle sosyal medyanın insanların hayatında çok fazla yer edindiği göz önüne alındığında, ders kitaplarında sosyal medya mesajları ile ilgili metinlerin olması gerektiği düşünülmektedir. Türkben (2018) dilekçe, e posta, özlü sözler, sosyal medya mesajları, çizgi roman, mizahi fıkra, ninni ve tekerleme gibi bazı türlere 5 . sınıf ders kitaplarında yer verilmediğini ifade ederken Kıbrıs (2019) 5. sınıf ders kitabındaki metinlerin tür açısından çeşitliliğine karşın öğrenme süreçlerinde film, kısa film, animasyon, görsel okur-yazarlık, medya okuryazarlığı vb. metinlerin sayısının artırılması gerektiğini ifade etmektedir. Söz konusu araştırmacıların (Türkben, 2018 ve Kıbrıs, 2019) farklı çalışmalarda inceledikleri kitaplardan birinin bu çalışmada incelenen kitaplardan biri ile aynı olması (5. sınıf Türkçe ders kitabı) ve üç çalışmanın da önemi gittikçe artan türlerin bir kısmına söz konusu ders kitabında ya hiç yer verilmediği ya da çok az yer verildiği konusuna dikkat çekmeleri önemlidir. Bu durum, kitapların hazırlanmasında önemli detaylara dikkat edilmediğini ve bu yönüyle özensiz hazırlandığını göstermektedir. Burada belirtilen eksikliklerin ders kitapları için oldukça önemi haiz olduğu yadsınamaz bir gerçektir.

Çalışmada incelenen kitapların, 2018 Türkçe Dersi Öğretim Programı'nda belirtilen zorunlu temalara dört sınıf düzeyinde de uydukları görülmektedir. Ancak ders kitabı yazarlarının tercihine bırakılan temaların seçiminde aynı hassasiyetin gösterildiği söylenemez. Kitaplarda zorunlu temaların dışında, "Doğa ve Evren" (4), "Okuma Kültürü" (3), "Zaman ve Mekân" (3), "Bilim ve Teknoloji" (2), "Kişisel Gelişim" (2), "Sanat" (2) "Çocuk Dünyası" (1), "Sağlık ve Spor" (1), "Birey ve Toplum" (1) ve "iletişim" (1) temaları olmak üzere 13 seçmeli temanın 10'una yer verildiği tespit edilmiştir. Bu durum, ders kitaplarının tema çeşitliliği açısından zengin olduğunu göstermektedir. Literatüre bakıldığında örgün eğitim veren okullarda okutulan Türkçe ders kitaplarının da tema bakımından zengin olduğu ifade edilmiştir (Türkben, 2018). Ancak seçmeli 13 temanın üçüne (Vatandaşlık, Duygular ve Hak ve Özgürlükler) hiçbir sınıf seviyesinde yer verilmemesi bir eksiklik olarak değerlendirilebilir.

"Doğa ve Evren" teması, her sınıf seviyesinde yer verilen tek temadır. "Zaman ve Mekân" (6, 7, 8) ile "Okuma Kültürü" $(5,7,8)$ temalarına ise üç sınıf seviyesinde yer verilmiştir. Özellikle Açık Öğretim Ortaokulu yoluyla öğrenimlerine devam eden bireyler düşünüldüğünde "Okuma Kültürü" temasına bu denli yer verilmiş olması önemlidir. Ancak bu temaya dört sınıf seviyesinde de yer verilmesinin daha 
yararlı olacağı değerlendirilmektedir. Özbay ve Çeçen (2012) yaptıkları çalışmada "Okuma Kültürü" temasının Türkçe dersleri içinde farklı bir yeri olduğunu ve bu temanın Türkçe ders kitaplarında yer alması gerektiğini vurgularken Türkben (2018), çocuğa okuma alışkanlığının kazandırılması açısından "Okuma Kültürü" temasının çok önemli olduğunu ve bu temanın da zorunlu temalar içerisine dâhil edilmesi gerektiğini belirtmektedir.

Ders kitapları hazırlanırken tema ve tür seçiminin çok önemli olduğu bilinen bir gerçektir. Zorunlu temalar çıkarıldığında, Program'da belirtilen 13 seçmeli temanın içinden her sınıf seviyesinde 5 tema seçilmektedir. Yukarıda belirtildiği üzere yazarların tercihine bağlı olarak ders kitaplarında bazı temalar her sınıf seviyesinde, bazıları iki veya üç sınıf seviyesinde, bazıları bir sınıf seviyesinde yer alırken bazıları da hiçbir sınıf seviyesinde yer almamıştır. Programda yer alan bütün temaların dört yıllık Açık Öğretim Ortaokulu süresince en az bir defa ders kitaplarında yer almasının doğru olacağı değerlendirilmektedir. Çünkü her temanın öğrenciye sağlayacağı pek çok katkı bulunabilir (Özbay ve Çeçen, 2012). Açık Öğretim Ortaokulu ders kitaplarının MEB Yayınevi tarafından hazırlandığı da göz önüne alındığında bunun uygulanabilirliğinin daha mümkün olduğu söylenebilir.

Ayrıca kitaplar hazırlanırken her temaya, uygun türden uygun metinlerin seçilerek türlerin temalara dengeli bir şekilde dağıtılması için gerekli hassasiyet gösterilmelidir. Ancak bunun ders kitapları yazarları açısından kolay olmadığı bilinen bir gerçektir. Zaten 2018 Türkçe Öğretim Programı'nda da bu durumun zorluğu düşünülmüş, her metin türünün her tema için uygun olmadığından hareketle şu ifadelere yer verilmiştir:

Belirtilen metin sayıları içinde kalmak kaydıyla hangi temada, hangi metin türlerinin yer alacağı ders kitabı yazarının/yazarlarının tercihine bağııdır. Metin türlerinin dengeli dağılıp dağılmadığı metin biçimlerine göre belirlenecektir. Örneğin "Bilim ve Teknoloji" temasında bilgilendirici metin daha fazla olabilir. Başka bir temada ise şiir türündeki metinlere daha fazla yer verilebilir. Ancak ilke olarak metin türlerinin temalar arasında, kitap bütününde dengeli bir şekilde dağılımının sağlanması esastır (s. 17).

Program'da belirtilen bu kıstas doğrultusunda temaların yapısına uygunluğu da göz önüne alınarak türlerin dengeli dağıtılmasına çalışıımalıdır.

\section{Öneriler}

Çalışmada ulaşılan bulgulardan hareketle şu öneriler geliştirilmiştir:

- Açık Öğretim Ortaokulunda okutulan Türkçe ders kitapları hazırlanırken okuma metinlerinin yanı sıra birer dinleme ve serbest okuma metni konulmalıdır.

- Bu okul için hazırlanan Türkçe ders kitaplarına, tiyatro ya da sınıf ortamında canlandırılması gereken diyalog ağırlıklı türler gibi açık öğretim ve uzaktan eğitime uygun olmayan türler alınmamalıdır. Bunların yerine ders kitaplarında hiç yer verilmeyen türlere öncelik verilmeli; yeni ve güncel türlerle anı, masal, makale, fıkra, biyografi/otobiyografi gibi uygun türlerin sayısı çoğaltılmalı; şarkı/türkü türüne de olanaklar ölçüsünde her sınıf düzeyinde yer verilmelidir.

- "Vatandaşlık", "Duygular" ve "Hak ve Özgürlükler" gibi önemli temaların dört kitabın hiçbirisinde yer almadığı görülmüştür. Öğrencilerin dört yıllık ortaokul sürecinde, Program'da yer verilen bütün temalarla en az birer defa karşılaşması sağlanmalıdır.

- 7. sınıf ders kitabında yer alan türlerin kitabın geneline ve temalara dengeli bir şekilde dağıtılmadığı, kitapta bilgilendirici metinlerin türlerin dağılım dengesini bozacak şekilde fazla olduğu, "Okuma Kültürü" temasında sadece bilgilendirici metinlerin yer aldığı görülmüştür. Söz konusu kitabın yeniden gözden geçirilerek bu tür eksiklikleri giderilmelidir.

\section{Kaynakça}

Akyol, H. (2013). Programa uygun Türkçe öğretim yöntemleri. Ankara: Pegem Akademi.

Altunkaya, H. (2013). Açık Öğretim Ortaokulu altıncı sınıf Türkçe ders notunun metin türleri ve öğrenme alanları açısından incelenmesi. Ana Dili Eğitimi Dergisi, 1(3), 1-11.

Aytaş, G. (2006). Edebî türlerden yararlanma. Milli Eğitim Dergisi, 169, 261-275. 
Binyazar, A. (1983). Ana dili öğretiminde yazınsal alanlar açılım. Türk Dili Dergisi, Dil Öğretimi özel Sayısı, 57-73.

Boratav, P. N. (2018). Zaman zaman içinde. Ankara: İmge Kitabevi Yayınları.

Cansız Aktaş, M. (2014). Nitel veri toplama araçları. Mustafa Metin (Ed.). Kuramdan uygulamaya eğitimde bilimsel araştırma yöntemleri İçinde (s. 337-371). Ankara: Pegem Akademi.

Ceran, D. ve Bozarslan, Y. (2013). illköğretim ikinci kademe 7. sınıf Türkçe ders kitaplarında yer alan "Millî Kültür" temasındaki metinlerin nicelik ve Türkçe Programı'na uygunluk açısından değerlendirilmesi. Ahi Evran Üniversitesi Kırşehir Eğitim Fakültesi Dergisi (KEFAD), 14(1), 271286.

Coşkun, E. (2005). illköğretim dördüncü ve beşinci sınıf öğretmen ve öğrencilerinin yeni Türkçe Dersi Öğretim Programı'yla ilgili görüşleri üzerine nitel bir araştırma. Kuram ve Uygulamada Eğitim Bilimleri, 5(2), 421-476.

Creswell, J. W. (2005). Educational Research: Planning, Conducting And Evaluating Quantitative and Qualitati And Research. USA: Pearson Prentice Hall.

Çeçen, M. A. ve Çiftçi, Ö. (2011). Türkçe derslerinde tematik eğitim ve metin-tema-alt tema ilişkisi üzerine bir araştırma. G. L. Uzun ve Ü. Bozkurt (Ed.), Türkçenin eğitimi-öğretiminde kuramsal ve uygulamalı araştırmalar içinde (s. 445-457). Essen/Almanya: Die Blaue Eule.

Çepni, S. (2012). Araştırma ve proje çalışmalarına giriş. Trabzon: Celepler Matbaacılık.

Demir, C. (2006). Türkçe/edebiyat eğitimi ve kişisel kelime serveti. Milli Eğitim Dergisi, 169, 207-225.

Derman, S. (2008). Dil bilgisi öğretiminde metinlerin seçimi üzerine bir araştırma. Doktora Tezi. Selçuk Üniversitesi Sosyal Bilimler Enstitüsü, Konya.

Güneş, F. (2013). Türkçe öğretimi yaklaşımlar ve modeller. Ankara: Pegem Akademi.

Güneş, F. (2013a). Türkçede metin öğretimi yerine metinle öğrenme. Adıyaman Üniversitesi Sosyal Bilimler Enstitüsü Dergisi, Türkçenin Eğitimi Öğretimi Özel Sayısı, 11, 603-637.

Güneş, F. (2013b). Türkçe öğretiminde metin seçimi. Ana Dili Eğitimi Dergisi, 1(1), 1-12.

Karasar, N. (2007). Bilimsel araştırma yöntemi. Ankara: Nobel Yayın Dağıtım.

Kaya, Z. (2002). Uzaktan eğitim. Ankara: Pegem A Yayınları.

Keklik, S. (2009, Mayıs). 1-8. sınıf Türkçe dersi ders kitaplarının metin türleri ve özellikleri açısından incelenmesi. I. Uluslararası Türkiye Eğitim Araştırmaları Kongresi'nde sunulmuş bildiri. Çanakkale Onsekiz Mart Üniversitesi, Çanakkale.

Kemiksiz, Ö. (2015). Türkçe derslerindeki dinleme metinlerinde dinleme yöntem/tekniği-metin türü arasındaki ilişkisi. Ana Dili Eğitimi Dergisi, 4(1), 15-30.

Kıbrıs, S. (2019). Ortaokul (5-8. sınıflar) Türkçe Dersi Öğretim Programı ve ders kitaplarında 'metin türü farkındalığı'. Yüksek Lisans Tezi, Başkent Üniversitesi Eğitim Bilimleri Enstitüsü, Ankara.

Kolaç, E. (2009). Illköğretim Türkçe ders kitaplarında yer alan metinlerin tür açısından değerlendirilmesi. Uluslararası Insan Bilimleri Dergisi, 6(1), 595-626.

MEB (2005). Illköğretim Türkçe dersi $(6,7,8$. sınıflar) öğretim programı. Ankara: Milli Eğitim Basımevi. MEB (2006). ilköğretim Türkçe dersi (6, 7, 8. sınıflar) öğretim programı. Ankara: Milli Eğitim Basımevi.

MEB (2018). Türkçe dersi öğretim programı (1, 2, 3, 4, 5, 6, 7 ve 8. sınıflar). Ankara: Milli Eğitim Basımevi.

MEB (2019). Türkçe dersi öğretim programı (1, 2, 3, 4, 5, 6, 7 ve 8. sınıflar). Ankara: Milli Eğitim Basımevi.

MEB Hayat Boyu Öğrenme Genel Müdürlüğü Açık Öğretim Ortaokulu. (2020). Okulumuz. 2 Mayıs 2020 tarihinde http://aio.meb.gov.tr/www/okulumuz/icerik/2 sayfasından erişilmiştir.

MEB Mevzuat. (2001). Milli eğitim bakanlığı açık öğretim ortaokulu yönetmeliği (beşinci bölüm-eğitimöğretim). T.C. Resmi Gazete (Sayı: 24561) içinde. 1 Mayıs 2020 tarihinde http://mevzuat.meb.gov.tr/dosyalar/73.pdf sayfasından erişilmiştir.

Mert, E. L. (2013). Türkçe ders ve çalışma kitaplarının sözcüksel görünümlerine ilişkin örnek bir uygulama. Dil Eğitimi ve Araştırmaları Dergisi, 4(3), 160-174.

Miles, M. B. ve Huberman, A. M. (2015). Genişletilmiş bir kaynak kitap nitel veri analizi. [Çev. Ed. S. Akbaba Altun - A. Ersoy (Giriş Bölümünü Çev. A. Ç. Kılınç)]. Ankara: Pegem Akademi. 
Özbay, M. ve Çeçen, M. A. (2012). Türkçe ders kitaplarında (6-8. sınıflar) yer alan metinlerin tür ve tema açısından incelenmesi. Dil ve Edebiyat Eğitimi Dergisi, 1(1), 67-76.

Polat, T. (1991). Ortaokullarda Türkçe: Türkçe dersleri I. Ş. Özil ve N. Tapan (Yay. Haz.), Türkiye'nin ders kitapları ortaöğretim ders kitaplarına eleştirel bir yaklaşım içinde (s. 15-33). İstanbul: Cem Yayınevi.

Sağır, M. (2002). ilköğretim okullarında Türkçe dil bilgisi öğretimi. Ankara: Nobel Yayın Dağıtım.

Sarıkaya, B. (2018). Metin yazma. M. N. Kardaş ve R. Koç (Ed.), Kuram ve uygulamada Türk Dili I içinde (s. 223-240). Ankara: Pegem Yayıncılık.

Sever, S. (2011). Türkçe öğretimi ve tam öğrenme. Ankara: Anı Yayıncılık.

TDK Güncel Türkçe Sözlük. Metin. 28 Nisan 2020 tarihinde https://sozluk.gov.tr/ sayfasından erişilmiştir.

TDK Güncel Türkçe Sözlük. Tema. 30 Nisan 2020 tarihinde https://sozluk.gov.tr/ sayfasından erişilmiştir.

Türkben, T. (2018). Ortaokul Türkçe ders kitaplarındaki metinlerin tür ve tema açısından incelenmesi. Hitit Üniversitesi Sosyal Bilimler Enstitüsü Dergisi, 11(3), 2152-2166.

Yalçın, A. ve Aytaş, G. (2011). Çocuk edebiyatı. Ankara: Akçağ Yayınları.

Yenen Avcı, Y. (2016). Açık Öğretim Ortaokulu ile örgün eğitim kurumlarında okutulan Türkçe ders kitaplarının karşılaştırılması. Eğitim ve Öğretim Araştırmaları Dergisi, 5(1), 153-160.

Yenen Avcı, Y. (2019). Açık Öğretim Ortaokulu 5. sınıf Türkçe ders kitabına eleştirel bir bakış. Uluslararası Eğitim Bilimleri Dergisi, 6(21), s. 95-109.

Yıldııı, A. ve Şimşek, H. (2008). Sosyal bilimlerde nitel araştırma yöntemleri. Ankara: Seçkin Yayıncılık.

\section{İncelenen Kitaplar}

MEB (2018). Ortaokul ve Imam Hatip Ortaokulu ders kitabı 5. Ankara: Milli Eğitim Bakanlığı Yayınları.

MEB Hayat Boyu Öğrenme Genel Müdürlüğü Açık Öğretim Daire Başkanlığı (2019). Türkçe 6. Ankara: MEB Hayat Boyu Öğrenme Genel Müdürlüğü Yayınları.

MEB Hayat Boyu Öğrenme Genel Müdürlüğü Açık Öğretim Daire Başkanlığı (2019). Türkçe 7. Ankara: MEB Hayat Boyu Öğrenme Genel Müdürlüğü Yayınları.

MEB Hayat Boyu Öğrenme Genel Müdürlüğü Açık Öğretim Daire Başkanlığı (2019). Türkçe 8. Ankara: MEB Hayat Boyu Öğrenme Genel Müdürlüğü Yayınları.

\section{Extended Abstract}

\section{Introduction}

Texts are literary constructions that consist of the hierarchical arrangement of sounds, syllables, words, and sentences and contain all kinds of information, emotions, and thoughts that we intend to convey.

The constructivist Turkish education curricula, which were implemented for the first time in the first and second grades of primary education in 2005 and 2006, respectively, focus in language teaching on learning with texts rather than teaching texts.

The 2005 constructivist curricula were the first to take thematic approach into account. Primary Education Turkish Course (Grades 1-5 and 6, 7, 8.) Curriculums (2005-2006) are some of them.

Literary genres are the first things that come to mind when we think of text types. In the 2018 Turkish course curriculum, the text types in the textbook are grouped under three categories; informative, narrative, and poetry.

Unlike formal education, open education is a system where teachers and students do not have to communicate by means of the traditional face-to-face classroom environment. A growing number of students who discontinue their formal education owing to various reasons enroll in open education secondary school, high school or college.

The study determined what kind of themes and texts consisted of in the 2019-2020 open education secondary school fifth-, sixth-, seventh-, and eighth-grade Turkish textbooks. The study investigated whether the books addressed the compulsory themes in the 2018 Turkish curriculum, if so, which of the themes they addressed, which text types they contained and which ones they never 
did, and whether the texts were distributed equally to the themes and the whole book. Therefore, the general aim of the study was to analyze the texts in the 2019-2020 open education secondary school fifth-, sixth-, seventh-, and eighth-grade Turkish textbooks in terms of type and theme. In this context, the study sought answers to the following questions:

In open education secondary school Turkish textbooks;

1. What are the numbers, types of text they are and how often they made use of kind of texts?

2. How is the distribution of the text types, included in the overall of the books and theme?

3. Which themes are included?

4. Which themes are most frequently included, are there any non-included themes, and if any, which ones?

\section{Method}

This was a document review, which is a qualitative research method. Data were analyzed using document review, which is a qualitative research method. First, a literature review was conducted to construct a theoretical foundation. Relevant articles, theses, and other scientific studies were examined, and then, the texts in the open education secondary school fifth-, sixth-, seventh-, and eighth-grade Turkish textbooks were analyzed in terms of text types and themes. The study material consisted of the 2019-2020 open education secondary school fifth-, sixth-, seventh-, and eighth-grade Turkish textbooks of the Ministry of National Education (MNE). Data were analyzed using descriptive analysis

\section{Results, Conclusion, and Recommendations}

- The MNE open education secondary school fifth-grade Turkish textbooks is the same as the formal education secondary school fifth-grade Turkish textbook.

- Each of the open education secondary school fifth-, sixth-, seventh-, and eighth-grade Turkish textbooks has 24 reading texts (96 in total). Of these reading texts, 40 are informative, 31 narrative, and 25 poetry.

- The fifth-grade textbook has 13 different types of texts while the sixth-, seventh-, and eighth-grade textbooks have 11 different types of texts.

- The textbooks contain poetry-type texts the most, followed by stories.

- The textbooks of all grades are supposed to include memoirs, e-mails, letters, quotations, social media messages, comics, novels, fables, cartoons, fairy tales, and songs/folk music. Three are supposed to include blogs, travel articles, and petitions. Two are supposed to include diaries and biographies/autobiographies. However, in reality, the textbooks address memoirs and fairy tales only twice, and letters, cartoons, and fables only once, and contain no texts of other types.

- The textbooks never address the themes of citizenship, emotions, and rights and freedoms.

The results show that the textbooks are rich in text-type and theme but have some shortcomings. Open education secondary school students do not receive any face-to-face education, and therefore, open educational books should be prepared more carefully. 